\title{
ACHMAT DANGOR (1948-2020) AND M.G. VASSANJI (1950-): THE RECEPTION OF TWO AFRINDIAN VOICES IN SPAIN
}

\author{
Juan Miguel Zarandona \\ Universidad de Valladolid (Soria)
}

\begin{abstract}
Dangor (Johannesburg, 1948-2020) and Vassanji (Nairobi, b1950) are two contemporary Indian-African ("Afrindian") diasporic writers who share a hybrid combination of Indianness and Africanness. Both writers have been translated into Spanish and, in the case of Vassanji, Catalan. The number of translations is rich enough to establish many description-based contrasts, and the proposal of future guidelines for translating Afrindian writers. The description takes into account the powerful autobiographical overtones typical of African writing, and describes how they have been made available to Spanish readers. A representative sample of exoticizing textual units from the original texts will be compared with their translation solutions in order to explore if exoticizing is the right method for this kind of postcolonial African Indian literature. The results indicate that exoticizing has been clearly favoured by the translators.
\end{abstract}

Keywords: Achmat Dangor, Moyez G. Vassanji, Indian-African Letters, English-Spanish Translation, Autobiography.

\author{
ACHMAT DANGOR (1948-2020) Y M.G. VASSANJI (1950-): \\ LA RECEPCIÓN DE DOS VOCES AFROINDIAS EN ESPAÑA
}

\section{RESUMEN}

Dangor (Johannesburgo, 1948-2020) and Vassanji (Nairobi, 1950-) son dos escritores contemporáneos pertenecientes a la diáspora indoafricana (afrindios) que comparten una naturaleza hídrida de indianidad y africanidad. Ambos han sido traducidos al español, además de al catalán para el caso de Vassanji. El número de traducciones es suficientemente abundante para plantearse contrastarlas desde un enfoque descriptitivo y proponer una serie de directrices para la traducción de otros escritores afrindios. Se tomarán, igualmente, en consideración los fuertes rasgos autobiográficos de la escritura africana al compararse una muestra representativa de unidades exotizantes de los textos originales con las soluciones de traducción aplicadas. Los resultados indicaran que este ha sido realmente la opción preferida de los traductores y lo que parece más adecuado para traducir la literatura afroindia poscolonial.

Palabras clave: Achmat Dangor, Moyez G. Vassanji, letras indoafricanas, traducción inglés-español, autobiografía.

DOI: https://doi.org/10.25145/j.recaesin.2021.82.09

Revista Canaria de Estudios Ingleses, 82; April 2021, pp. 123-141; ISSN: e-2530-8335 


\section{INTRODUCTION}

This article draws its concepts, empirical data and inspirations from two main sources. First, according to the American scholar David Damrosch (2003), the concept of "world literature" in combination with "translation" has sparked new interest, especially in the context of postcolonial literature. Damrosch rejects the use of the term "world literature" to describe what is mostly the Western European literary canon, and proposes instead that it be used to describe literature that circulates beyond their countries of origin. In other words, "world literature" relies on a fruitful collaboration between the fields of Literary Theory and Translation Studies.

In the postcolonial context, more and more translations are being made from and among an unprecedented range of literary worlds, recognized and marginal (Tymoczko 1999). A good example of this trend, and my second source of inspiration, is the reception of postcolonial literature into the Spanish literary polysystem. Books (including translations) published in Spain circulate easily in Latin America, parts of the USA, and other areas of the world. This chapter considers two Spanish polysystems, in Castilian-Spanish and Catalan, both official languages of Spain. ${ }^{1}$

However, the reception of African Indian writing is generally marginal: “... so far a much neglected postcolonial entity" (Lal 2006: 253), and therefore deserves further attention. Although scholars like Karpinsky (2012) acknowledge the contributions of African Indian writers, this group is generally overlooked by scholarship. For example, in their volume on autobiographical South African writing, Cornwell et al. (2010) overlook works from the diasporic South African Indian community, even neglecting such cultural icons as Mahatma Gandhi (1869-1948), Ronnie Govender (b1934) and Imraan Coovadia (b1974) (see also Daymond 2018; Roy 2018). A similar neglect is noted in Arkin et al. who comment that "[I]n the field of creative literature, however, Indians have not distinguished themselves as other South Africans have. Only a handful of writers have had their work published and no major writer has emerged so far" (1989: 201). Govinden (2008: 19) notes that this ignorance of African Indian writing has negative international consequences in terms of the reception of such works. It is evident that this literature still has to conquer its own readership both at home and abroad (Rastogi 2008).

Efforts to address this neglect led to the foundation of the "Ratnakara Research Group. Indian Ocean Literatures and Cultures," based at the Department of English at the Autonomous University of Barcelona in the 1990s and founded by Felicity Hand and Esther Pujolràs-Noguer. As Hand and Pujolràs-Noguer describe it:

Ratnakara, a Sanskrit term for "ocean" and "repository of jewels," encapsulates the rationale behind our research group.We envisage the Indian Ocean as a mine of cultural experience with multiple connections that link the countries of its western shores with the Indian subcontinent, a relationship that was thriving centuries

\footnotetext{
${ }^{1}$ Spain has four official languages: Castilian or Spanish, Catalan, Galician and Basque.
} 
before the Europeans set foot in the area thanks to the Monsoon winds. Our group seeks to uncover the richness of the cultures and literatures of the region, ranging from Kenya to South Africa and not forgetting Mauritius, the star and key to the Indian Ocean (Ratnakara, online).

Ratnakara has contributed to the recognition of South African Indian writer Ahmed Essop (see Zarandona 2015, 2016, 2018) as one key figure in the world of Indian Ocean literature and its consequent translation of Essop's short story Two Sisters (1978), into Spanish as Dos hermanas (Essop 2010) testifies to this. Zarandona (2018a) addresses how race plays an influential role in the reception of South African literature in Spain. While white writers such as Nadine Gordimer and J.M. Coetzee are well received, and some black writers such as Zakes Mda have a moderate following, translations of South African Indian literature are rare.

In this paper, I explore the writings and translations of two contemporary African Indian writers, the South African Achmat Dangor (1948-2020) and the Kenyan-Canadian Moyez Vassanji (b1950). Both authors have been translated into Spanish, and Vassanji also into Catalan. Of Dangor's ten works spanning from 1981 (Waiting for Leila) to 2017 (Dikeledi Novel), three have been translated into Spanish. These are: The Z Town Trilogy (1990) translated as Trilogia de Z Town (2009) by Juan Estrella; Kafka's Curse (1997) translated as La Maldición de Kafka (1999) by Encarna Quijada Vargas; Bitter Fruit (2001) translated as Fruta amarga (2004) by María Montserrat Vía. Of Vassanji's fourteen works spanning from 1989 (The Gunny Sack) to 2019 (A Delhi Obsession), only one, The In-Between World of Vikram Lall (2003) has been translated into Spanish as El mundo incierto de Vikram Lall (2006) by Gemma Rovira Ortega. It has also been translated into Catalan as La pàtria aliena de Vikram Lall (2006) by Xavier Pàmies Jiménez.

Both writers are African, Indian, minority, postcolonial, diasporic, hybrid and contemporary. Not only do their works enlarge the English-language literature canon and make it more inclusive, but they also promote the richness and complexity of "world literature," specifically the Spanish literary polysystem.

However, although there is no doubt about their Africanness or contemporaneity, for example, the adjective "minority" must be handle more carefully. Indian literature in English has been consistently taught in Departments of English around the world, most specially those in English-speaking universities. Recent studies such as The Indian English Novel. Nation, History, and Narration (2009), by P. Gopal, prove this. ${ }^{2}$ And some of the Indian or Indian diasporic texts and writers have not only known a great academic success, but a popular one too. But it is also true that these literary works are still far from occupying the centre of the English language world literary polysystem. Besides, both Dangor and Vassanji belong to the African-Indian diaspora. Dangor always lived in South Africa, which means that he suffered all the discrimination that his community endured for so many

${ }^{2}$ Gopal includes three pages on Vassanji (2009: 172-174), but does not mention Dangor. 
years. And Vassanji only started his literary career once he settled down in Canada. Finally, the minority status is more perfectly appreciated when we approach other international polysystems, such as the ones on Spain, both in Spanish and Catalan, where their texts in translation occupy a very marginal position.

\section{COMPARISON OF TWO AFRINDIAN WRITERS}

"Afrindian" is a term popularized by scholar Pallavi Rastogi (2008), who applied it to the South African Indian community and their complex struggle to find an identity, and to describe their long fight for recognition and acceptance in their country. They feel themselves to be first South Africans, and then members of the large diasporic Indian world. The term derives from Lal's (2006) monumental Encyclopedia of the Indian Diaspora, where he describes the South African Indian diaspora through the term "Afroindian." According to Lal, "Afrindian' therefore symbolizes the Africanization of the Indian self in a unique intersection of diaspora, postcoloniality, Indianness, apartheid, and black/white binary oppositions" (242). Specifically referring to Dangor, Lal further comments on the uniqueness of South African Indian literature, "that reflects distinct South African realities, so far a much neglected literary postcolonial entity" (253).

Dangor, born in 1948 in Johannesburg, is therefore representative of the relatively successful (but discriminated under apartheid) South African Indian community. He remained in South Africa, and devoted himself entirely to writing until 6 September, 2020, when he died. He won numerous prizes, including the South African Bosman prize for Kafka's Curse; and Bitter Fruit was shortlisted for the Booker Prize in 2004. He was also given the Lifetime Achievement Award by the South African Literary Awards (SALA). He taught creative writing and South African literature at City University of New York. He was President of the Nelson Mandela Foundation. His first published work belongs to the year 1981, when he started a professional career fully devoted to letters (novels, short stories, novellas, poetry).

Dangor's uniqueness is emphasized by Ronit Frenkel (2010), who claims that Dangor confounds unitary taxonomies in both his writings and his identity. He has been listed both as Indian and as "Coloured," a category imposed on a heterogenuous group of people originating from areas as diverse as India, Madagascar, East Africa, West Africa, Indonesia and Malaysia. The British Council (S.A.) webpage on English language literature includes an entry on Achmat Dangor that explains this ambiguity clearly: ${ }^{3}$

3 The unavoidable elusiveness of the term "coloured" indicated the absurdity behind the whole racial identity classification in apartheid South Africa. 
I am an African with Asian and Dutch blood in me, I don't know what race I am, and I don't care" -this is how South African poet and novelist Achmat Dangor, born into an Indian and Muslim family in Johannesburg, describes himself. This description, together with Dangor's literary production, is a poignant reminder of the absurdity and arbitrariness of racial categories. The institutionalization of racial typologies can only give rise to racist regimes such as South Africa's apartheid. Thus, Dangor's fiction and poetry unsettle superficially-drawn racial divisions and challenge societies built on racial codes.

Some of Dangor's characters mirror his hybrid identity. For example, Oscar, one of the protagonists in his novel Kafka's Curse (1997) is described as follows:

What they really meant was: Oscar's not one of us. He was a mixture, Javanese, and Dutch, and Indian, and God knows what else, they would later discover. $\mathrm{He}$ was the lovely hybrid whom Anna had fallen in love with, perhaps because of his hybridity (11).

I propose that the term "Afrindian," though coined in South African territory could also be applied to East African Indians like Vassanji. As the Encyclopedia of the Indian Diaspora also outlines (Lal 254-262), they, or their ancestors, first travelled from India to East Africa, and then a great part of them were forcibly repatriated from Africa in the 1970s, many moving to Great Britain, the United States of America and Canada. Their two migrations, their two diasporas, have also been narrated in an Afrindian literature. ${ }^{4}$

Vassanji, born in 1950 in Nairobi, Kenya, is therefore representative of this phenomenon. When his father died, his mother decided to move to Tanzania in order to be among her own family members. And in 1978 he moved to Canada where he got a grant and trained as a nuclear physicist at MIT and taught in different universities before devoting himself to writing. He is a Fellow of the Indian Institute of Advance Study in Shimla, India, and has won numerous awards, including the Commonweath Prize, the Bressani Prize, and Giller Prize (twice), Canada's most prestigious literary award. From 1989 and ever since he has been fully devoted to literature, as a writer and as an editor (he and his wife are in charge of Toronto Review of Contemporary Writing Abroad).

${ }^{4}$ It should be noticed that "Asians" -as they were referred to- were expelled by Idi Amin in Uganda -but they were not officially expelled from either Kenya or Tanzania. As a matter of fact, in the case of Tanzania and under Julius Nyerere's leadership, some "Asians" formed part of the Government. 


\section{AFRINDIAN LITERATURE: MINORITY, AUTOBIOGRAPHICAL AND DIASPORIC}

Afrindian literature is characterised by three main aspects: first, it is an example of minority writing, especially when you study how frequently and how succesfully it has been translated into the languages of Spain; second, it has strong autobiographical tones; third, it contains unique diasporic reflections on the Indian "homeland."

\section{Afrindian Literature as Minority Writing}

Among the efforts to define and describe the main characteristics of Afrindian literature, the words by Vijay Mishra (2006: 139) are specially illuminating and applicable to both Dangor and Vassanji. He claims that the literature of the Indian diaspora is arguably one of its greatest accomplishments, as the literature produced is among the best writing in English since the mid-20 $0^{\text {th }}$ century. Mishra (2006: 139) notes that it is a minor literature written in a major language: ${ }^{5}$

The use of the term "minor literature," therefore, signals a number of formal characteristics of the literature of the Indian diaspora: it removes the absolute link between peoples and mother tongues... it places the writer in the midst of the greater concerns of the nation even when he or she may be seen as an outsider; and it voices, through a thoroughly nuanced use of English, something that belongs specifically to a diasporic group consciousness. The literature of the Indian diaspora as an example of a minor literature suggests that a minor literature does not come from a minor language but it is something that a minority constructs in the majority language, in this case predominantly English... As a minor literature reflecting these characteristics, the literature of the Indian diaspora is bold, imaginative and foundational.

The Canadian scholar Eva Karpinsky $(21,25)$, in her book Borrowed Tongues. Life Writing, Migration, and Translation, studies the phenomenon involving diasporic minorities writing about their experience and indentity in a borrowed major language by means of (un)conscious acts of translation from their mother tongues:

Spanning the axis between "mother tongue" and "borrowed tongue," translation for a migrant encodes the tensions between the two and can be experienced through metaphors of movement and displacement, as exile from one or the other, tinted with nostalgia for either language, or as exile from both, the mother tongue and the borrowed tongue (21) [...] Writing in English, either as the language of symbolic empowerment for many immigrants, or as the language of historical oppression for

\footnotetext{
${ }^{5}$ Although Mishra does not mention it, these laudatory words must also be applied to Afrindian literature in English.
} 
many indigenous and postcolonial subjects, already "disarticulates" the original, and therefore exposes violence inherent in the act of translation (25).

\section{Afrindian Literature as Autobiographical Postcolonial Writing}

"Autobiography" has always been a fuzzy category in literary theory, ranging from any fiction writing that has some autobiographical elements related to its author, to a very distinct genre in which author, narrator, and protagonist are one and the same (Anderson 2011). The latter has enjoyed a long tradition of texts, e.g. Nelson Mandela's Long Walk to Freedom (1994). Indeed, it is difficult to identify differences between life-writing subgenres -biography, autobiography, travel books, memoirs, diaries and testimonies, and they also produce hybrids with other genres and subgenres. $\mathrm{Xu}$ (2017) notes that translating such autobiographical works presents many challenges. Cornwell et al. (17) claim that life writing (autobiography) has always been an effective medium of expression for African writers:

What is most distinctive about African autobiography is its concern to present not a unique existence but a representative life that helps to explain the historical circumstances that engendered it (Cornwell et al. 38).

Recent years have witnessed an explosion of interest in the so-called "autobiographical moment in postcolonial theory" (Huddart 2014), i.e. a movement away from focusing on the self-lives of white, Western men to exploring a varied assortment of new selves belonging to hybrid, diasporic, mobile, male/female subjects generated by colonialism or postcolonialism; what Ania Loomba (16-22) calls the contrasts between the binary opposition between colonial and postcolonial worlds.

The novels of Dangor and Vassanji are not strictly autobiographical, but include many autobiographical elements based on the life experiences of their authors. Dangor's The Z Town Trilogy (1990), Kafka's Curse (1997) and Bitter Fruit (2001) deal with the Indian community in South Africa during the apartheid and post-apartheid times from the viewpoint of their author's life experience. Similarly, Vassanji's The In-Between World of Vikram Lall (2003) is based on its author's experience of the predicament and hardships of the East African Indian community and their second diaspora. The epynomous protagonist of this novel, Vikram Lall, is an adult living in exile in Canada who contemplates his life as a teenager of Indian origin living in Kenya in the 1950s. The coincidences with Vassanji's own life experience are very clear (Gopal 172-174).

\section{Afrindian Literary Perspective of "Homeland"}

Many Indian diaspora writers, including Afrindian ones, such as Vassanji, have made the pilgrimage back to the "homeland," and the diverse nature of their return journeys has been captured in the memoirs they consequently wrote. Whereas V.S. Naipaul (1932-2018, born in Chaguanas, Trinidad, within a family 
who emigrated from northern India) and Michael Ondaatje (b1943 in Sri Lanka but emigrated to Canada) experienced this pilgrimage negatively, to Vassanji it was a positive experience. Naipaul's memoir Finding the Centre (1984) narrates his travel to what he perceived as "primitive" India for the first time, and Ondaatje's Running in the Family (1983) to his return to Sri Lanka. To both Naipaul and Ondaatje, the visit was portrayed as a horrible nightmare, a journey into a barren place which was the source of much frustration, because India and Sri Lanka had become alien lands to them.

By contrast, Vassanji's return, described in his autobiographical account $A$ Place Within: Rediscovering India (2008), meant his reconciliation with India, that distant land, the land of his grandparents. He managed to prove that it was possible for him to enjoy and be part of three different cultural and geographical backgrounds: East Africa, ${ }^{6}$ Canada, and India. His visit occurred shortly after he had published his novel The Assassin's Song (2007), set entirely in India, which was received as a novel of India, and not an Indian diaspora novel. For him, his "in-between" world has really turned into his "in-among" world.

Vassanji's positive yet realistic attitude is reflected in the following excerpt:

India has changed. The country brims with confidence, a refreshing contrast to the images of my youth (Life magazine) of starving, dying India. Embarrassing India. Now, on the sixtieth anniversary of Independence, the Times of India's headline is "60 and getting sexier"; tabloid language, unfortunately, is a marker of sophistication and coolness even in this established newspaper. The media talk is endlessly of the economy and growth rates and "Chindia" -the superpowers on the threshold, China and India; film celebrities, cricket, and America are the obsessions. America is to be emulated, competed against, bettered. Everything on television (if in English) gives the appearance of a studied mimicry of America. Cool India (the phrase itself lifted from Tony Blair's Cool Britannia) is to some degree Mimic India (Vassanji 2008: 148-149).

\section{RECEPTION OF AFRINDIAN WRITING IN SPAIN}

Although Afrindian writers may have reached a high status of international recognition for their postcolonial, Afrindian, autobiographical works, in Spain their status as worldwide authors is as yet unrecognized. As a matter of fact, the whole bulk of African literature falls prey to this lack of recognition in Spain. This is true even of great iconic authors such as Chinua Achebe (1930-2013). Nearly all his works have been translated into Spanish, and Things Fall Apart has been retranslated frequently. However, in Spain, only a tiny number of readers know him (Zarandona 2010). By contrast, the diasporic Indian writers V.S. Naipaul and Michael Ondaatje are well

${ }^{6}$ In 2014 he published his "African" memoir, And Home Was Kariakoo: A Memoir of East Africa in which his East African Asian essence was explored. 
known in Spanish translation -the Spanish ISBN Database includes seventy entries for Naipaul and twenty-nine for Ondaatje (Feb 20 2020). This is understandable as Naipaul is a Nobel Laureate and Ondaatje became very popular due to the film adaptation of his novel The English Patient (1992). However, Afrindian writers such as Dangor and Vassanji are, I argue, marginalized since even the fact of being translated does not guarantee a rich reception.

In his doctoral thesis, Fernández Ruiz (2019) lists a number of factors related to the poor reception of translated African literature in Spain. First, commercial publishers are not interested in publishing African literature in translation, so this kind of literature is only published when there is some kind of institutional support or sponsorship. Second, these translations are regarded as exotic second-class products limited to a minority of readers interested in other cultures, so publication is characterized by very short runs or small imprints (usually by small publishing houses) that do not survive for a long time. Third, there are no translators specialized in African literature.

\section{METHODOLOGY}

Christiane Nord (1997) proposes two types of translation: "instrumental translation," when the function of the target text (TT) dominates, and "documentary translation," when the source text (ST) function dominates. Documentary translation is also classified into four different types: interlineal, literal, philological and exoticizing. "Exoticizing translation" is the one typical of modern fiction prose: it strives to reproduce ST form, content, and situation, and may include textual units of the ST.

My research aim is to explore to what extent the Spanish translators have followed this exoticizing principle when translating Dangor and Vassanji. The principles of Descriptive Translation Studies (DTS), as established by Gideon Toury (2012), are also followed, in the sense that the empirical description of the translations must come first, and then the theorizing about them. ${ }^{7}$

Following this concept of "exoticising translation" and using a descriptive approach, my research methodology includes the following actions:

1) Choose one preliminary textual sample from each of the translations and describe whether an exoticising or domesticating strategy is applied.

7 Toury claimed that Translation Studies, as a new discipline, had to be provided with a sound descriptive or empirical branch upon which to base all theoretical reflection. This was something that was lacking so far. Translations are subject to time and historical context, so we can only study what was regarded as "translation" in a given time and place. In other words, the changing norms that have determined the concept of translation. And only when these norms are fully described and placed in time and space, translation scholars would be able to go a step forward and study invariable translation laws beyond time and space. 
2) Elaborate a hypothesis according to these preliminary samples.

3) Try to prove the hypothesis by selecting excerpts from the source texts (STs) and extracting all textual units (words, phrases, sentences, paragraphs) in languages other than English, and then comparing them with their corresponding units in the target texts (TTs). Proper nouns (individual people, place or commercial names, etc.) will be excluded. (For convenience, the STs and TTs are coded.) The following excerpts were selected for Dangor (D) and Vassanji's (V) original texts and their Spanish translations:

D1: The Z Town Trilogy, Part 2 "Birds of Prey" (pp. 35-91)

D2: Kafka's Curse, Chapter 2, "Majnoen" (pp. 21-41)

D3: Bitter Fruit, Chapters 1-3 (pp. 3-42)

D1-T: Trilogía de Z Town, "Aves de rapiña" (pp. 65-151)

D2-T: La maldición de Kafka, "Majnoen" (pp. 37-66)

D3-T: Fruta amarga, capítulos 1-3 (pp. 13-63)

V1: The In-Between World of Vikram Lall, Chapters 1-3 (pp. 3-45)

V1-T1: El mundo incierto de Vikram Lall, capítulos 1-3 (pp. 11-56)

V1-T2: La pàtria aliena de Vikram Lall, capítols 1-3 (pp. 13-46) ${ }^{8}$

\section{RESULTS}

With the aforementioned roadmap in mind, this is the first preliminary action carried out.

\section{Dangor's Preliminary textual units}

After a close reading of the whole texts, these first units for our preliminary analysis were chosen because of their very special cultural and linguistic characteristics, and for their symbolic value.

To begin with, a clear example of "exoticizing translation" can be seen here: a textual unit of the ST, the title of the South African anthem in an African language is kept, and sung by a multilingual chorus of characters. The translator adds a full explanation in a footnote for his Spanish readers who are not very likely to understand the emotional meaning of the song and its complex history as symbol of the struggle:

8 The very title of the novel, The In-Between World of Vikram Lall, involves a real challenge. It is the story of a man's conflict trapped in the perilous in-between of two different worlds, Africa and India (Gopal 2009: 172-174). The options taken by the two translators for "in-between world," as "mundo incierto" [uncertain world] (Spanish) and "pàtria aliena" [alien homeland] (Catalan), miss the complex meaning and intentions of the original. 
D1: Sarah Kock was buried with the pomp and ceremony fitting of the widow of a hero. And when the anthem was sung, Dorothy too lifted her fist to the proud strains of Nkosi Sikilel iAfrika though she and many others did not understand its words, but were filled with the beauty of its meaning (107).

D1-T: Sarah Kock fue enterrada con la pompa y la ceremonia que correspondía a la viuda de un héroe. Y cuando se cantó el himno, Dorothy también alzó el puño a los orgullosos acordes del "Nkosi Siklel iAfrika", porque aunque ni ella ni muchos otros comprendían el significado de aquellas palabras, se dejaban llevar por su belleza (172-173).

* (Dios bendiga África», himno de la Sudáfrica antiapartheid, posteriormente adoptado, con variaciones, como himno nacional. (N. del T.) ["May God bless Africa," hymn of anti-apartheid South Africa, later on adopted, with some variations, as the national anthem (my translation)]

Secondly, in this ST, the Afrindian character Malik is able to pronounce a whole sentence in Afrikaans (something not unusual in a multilingual society) and make fun of it. This fact reflects the former national policy by which everybody in South Africa had to learn Afrikaans. Malik's mocking is thus based on the fact that Afrikaans was the language of the oppressor. English-speaking South African Indians usually spoke it well, so the use of Afrikaans relevant in this linguistic context is especially marked.

The translator reproduces the whole textual unit without any explanation in the main text, which is really exoticizing. The compensation appears in a final glossary (217), a detailed paratext that solves all the linguistic and cultural difficulties that Spanish readers may encounter. However, surprisingly, the translator omits the name of the language, Afrikaans, in both the text and in the glossary. In my opinion, she seems to assume that her readers will not have any idea about the existence of this language, so she had better not complicate their understanding of the text any further.

Another item is the ST word "kofiya" (a typical Middle Eastern headdress). In the ST, the word is local, part of the South African Indian and other Muslim communities (not part of the general non-Muslim idiom), and therefore it is not given typographical emphasis. The translator rewrites it in italics, kofiya, which is the norm in Spanish for foreign words.

D2: He ignored the set of clothes, a dark suit, white shirt and red tie, the soft white kofiya, very similar to the one he wore himself, all neatly folded and displayed upon the seat of the chair.

"Ons mense begrawe nie hul dooies asof hulle op pad partytjie toe is nie," Malik said in Afrikaans, his tone mocking (44).

D2-T: No hizo el menor caso de las ropas que había pulcramente preparadas en una silla: traje oscuro, camisa blanca y corbata roja. La kofiya suave y blanca era muy similar a la que él mismo llevaba.

- Ons mense begrawe nie hul dooies asof hulle op pad partytjie toe is nie - dijo Malik en tono burlón (70-71). 
Glosario: (...) Ons mense begrawe nie hul dooies asof hulle op pad partytjie toe is nie: nuestra gente no entierra a sus muertos como si fueran de camino a una fiesta (217).

In the third place, the translator also chooses an exoticizing method, as she keeps the local word tsotsi in her text. As in the above textual units, the word appears in italics, as it is a foreign lexical unit in Spanish, and possible misunderstanding is compensated by means of a final glossary where three Spanish synomyns are offered (364).

D3: ... drinking in the street like a kid, or worse still, like a tsotsi who had taken to petty crime because he couldn't face life. (6).

D3-T: ... bebiendo en la calle como un niño, o todavía peor, como un tsotsi que había empezado a cometer delitos de poca importancia porque era incapaz de hacer frente a la vida. (17).

Glosario: (...) tsotsi: gandul, vago, gamberro (364).

\section{Vassanji's Preliminary teXtual units}

Finally, the Indian and African Indian word "Bauji" appears twice in this fourth ST text sample. The Spanish-language translator transfers it the first time as "bauji" (not capitalized and not in italics, the latter contravening Spanish convention), but for its second instance she chooses to explain it by means of the formal "padre" (father). Neither a footnote nor a glossary entry is provided. We only have this balance between one instance of exoticizing (bauji) and one of domestication (padre). By contrast, the Catalan translator (Xavier Pàmies) changes both instances of "bauji" to the informal "papa" (daddy). This indicates that this translator prefers a strategy of domestication, as here the exoticizing textual unit has been eliminated twice. The translator also ignores the fact that this solution can be regarded as too colloquial for the typical pragmatic uses of language and strict forms of address between younger and older generations within Afrindian family circles.

V1: Why don't you go back to India? I'd miss you, but you can go and make up with Bauji ... and I could even follow you later with my family.

He grunted. I could never make up with Bauji, not at this moment. (83).

V1-T1: -¿Por qué no vuelves a la India? Yo te echaría de menos, pero podrías hacer las paces con bauji... Y quizá dentro de un tiempo mi familia y yo podríamos reunirnos allí contigo.

-No podría hacer las paces con padre, de momento no -refunfuñó él-. (93).

V1-T2: ¿Per què no te'n tornes a l'Índia? Et trobaria a faltar, però podries fer les paus amb el papa; i fins i tot jo podria venir després, amb la família.

El tiet Mahesh va rondinar. No podria fer les paus amb el papa de cap manera, si més no ara. (77). 


\section{HYPOTHESIS}

The results of this preliminay survey indicate that Nord's theory seems to be correct. Therefore my working hypothesis is that "exoticizing translation" is the preferred strategy for the Spanish translators, but that there can be instances of translation that follow the opposite one, as the Catalan translator shows. However, it is also evident that all the translators are too prudent and afraid that their readers would not understand the texts without explanatory footnotes and glossaries, suggesting that Afrindian literature is considered too exotic for the average Spanish reader.

\section{CORPUS EXTRACTION}

If interested in the full corpus see: https://www.researchgate.net/project/ Afrindian-writers-in-Spanish-translation (Zarandona 2020). However, the main results that I have found are outlined in the coming parapraghs.

\section{DANGOR'S TEXTS AND THEIR SPANISH TRANSLATIONS: A GENERAL OVERVIEW}

In the $Z$ Town Trilogy extract (D1), I found 32 textual units in other languages, mostly (23) in Afrikaans. Afrikaans units include: short expressions

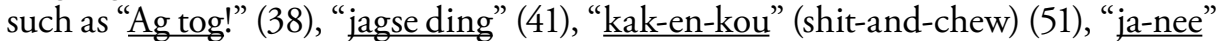
(60), as well as single words such as "Baas" (41), "skenner... skennervrou" (62). Occasionally, full sentences are included, such as "As jy nie off-jok nie gaan jy jou ma hier in die straat sien" (42).

The other nine samples include other South African languages, e.g. mampara (87, Zulu), Tsamaya (87, Sotho), Cape Coloured dialect, e.g. "Skora Skora" (72), Scabarash (47). Malay words, e.g. "ejaar" (77), and even one instance in French "avant garde" (56).

In the translated excerpts (D1-T), the translator Juanjo Estrella opted to transfer the ST units, mainly with explanations either in the text or in the glossary, e.g.: - $\underline{i \mathrm{Ag} \operatorname{tog} !}$ (67); $\underline{\mathrm{Baas}}(71)$ * $\underline{\mathrm{Bass}}$, «jefe» en afrikáans (71); «jagse ding», "cosa cachonda" (73); As jy nie off-jok nie gaan jy jou ma hier in die straat sien. Jane la reprendió, (73). Some instances of domestication are also present: «I, a Southern Black Tit» (60), «YYo, un carbonero negro meridional» (103); «I am not a skennervrou" (62), "No soy una chismosa" (62); or «Befok that ausie» (68), «Es rara esa forastera" (114).

Similarly, the samples in other languages evidenced mixed translation strategies, with some being transferred: «...the traditional ejaar that she wore...» (77), «...del ejaar tradicional que llevaba» (131) or «Masha-Allah! You look beautiful» (79), - Masha Allah. Está preciosa»; and others domesticated: «Hey wena, its time to get out of here'» (87), «Eh, tú, ya va siendo hora de que te largues de aquí» (146). 
The translator mirrors the multilingualism of the South African linguistic reality, retaining more than $50 \%$ of the original non-English textual units. It may seem that he reduces the level of exoticizing, but the result is still very exoticizing for Spanish readers. This strategy was probably the right balance between respecting the original and attaining understanding and acceptance in the target language and culture.

Kafka's Curse (1997: 21-41) and its translation (1999: 37-66) are very similar as far as this powerful stylistic device by Dangor is involved. The ST excerpt yielded 18 samples, 12 in Afrikaans, and the other six in Arabic, Hebrew, and Asian languages. The translator, Encarna Quijada Vargas, clearly favoured exoticizing, as she exoticizes, for example, "...this Helpmekaar Home?» (27), «...a los de esa Helpmekaar?» (46); «...the living shame of a white hoer» (30), «la vergüenza viviente de una hoer blanca» (50); or «... he looks like a chaar» (31), «...parece un chaar» (51).

Finally, Bitter Fruit (2001: 3-42) and its translation (2004; 13-63) yield similar results. The ST excerpt includes 17 relevant text units: 10 in Afrikaans, and the rest in Arabic and African languages (Swazi, Zulu, Sotho). The translator María M. Vía also favours exoticizing: «He remembered how the police made them "tauza” (15), «Recordó cómo la policía les había hecho tauza» (28); or «Her family calls him "ougat”...» (28); «Su familia le llama ougat» (46).

Thus, all three translators made very similar translation decisions when dealing with Dangor's Afrindian expressions.

\section{VASSANJI'S TEXTS AND THEIR SPANISH TRANSLATIONS: A GENERAL OVERVIEW}

Analysis of the ST excerpt yielded 49 text units in other languages. Words in Punjabi include the following: "bhajias," "samosas," "dhokras," "bhel-puri" (6). Local African languages' (Kikuyo, Masai) words and phrases include the following: "panga” (26), “Tokeni nje! Sasa hivi!" (31), ... Unlike Dangor who included whole sentences, Vassanji restricted exotic terms to single words or short phrases.

Both translators, Gemma Rovira Ortega (Spanish) and Xavier Pàmies (Catalan) make a real effort to keep this literary hybrid language in their target languages, i.e. their overall strategies are exoticizing:

V1: Indian families having stopped over in their cars for bhajias, samosas, dhokras, bhel-puri, and tea (6).

V1-T1: ... las familias indias se detenían allí con sus coches para comprar bhajias, samosas, dhikras, bhel-puri y té (16).

V1-T2: ... moltes famílies índies hi paraven amb el cotxe per comprar-hi bhajies, samoses, dhokres, bhel-puri i te (14).

V1: But mother was from India and not as intimidated by the angrez-log (as they called the Europeans) as Papa was (16). 
V1-T1: Pero mi madre era india, y no se dejaba intimidar tanto por los angrez-log (como llamaba ella a los europeos) como mi padre (26).

V1-T2: Però la meva mare era de l'Índia, i els angrez-log (com ella anomenava els europeus) no la intimidavem tant como al meu pare (22).

V1: The Mau Mau are devils, I said, echoing my mother. Her term was "daityas" from Mythology (27).

V1-T1: -Los mau-maus son demonios -dije, haciéndome eco de mi madre. La palabra que empleaba ella era daityas, de la mitología hindú (37).

V1-T2: Els Mau-Mau són dimonis, vaig dir, repetint el que deia la meva mare. La paraula que ella feia servir era el terme mitològic "daitya" (30).

However, the Catalan-language translator occasionally domesticates the ST items, e.g. "daal" (Va: 28) is translated as "llenties" (Vc: 23), "congresswallahs" (Va: 33) as "congressistes" (Vc: 28), and "panga" (Va: 36) as "matxet" (Vc: 30). He also adapts some of the original exotic words to the Catalan spelling and pronunciation systems, e.g. "àscaris” [askaris] (Vc: 25), "culi” [coolie] (Vc: 29).

Dangor's translators preferred exoticization: D1T $(40,6 \%)$, D2-T $(88,8 \%)$, D3-T (52,9\%). So did Vassanji's Spanish and Catalan translators: V1-T1 (90\%) and V1-T2 (80\%). It is quite evident that Spanish translators, into both Spanish and Catalan favour exoticising. These data confirm my hypothesis. When translating this kind of exotic texts, the addition of notes and/or glossaries seems to be the best option. If the translated text does not reach wider audiences, the explanation must be sought in cultural factors, not in linguistic ones.

\section{CONCLUSION}

This research project on the translations of the works by Achmat Dangor and Moyez G. Vassanji into two of the official languages of Spain is a fascinating initiatory journey of discovery with many practical applications. It involves literary translation from an African perpective, and as such, it contributes to current debates on colonialism and postcolonialism, world literature and its circulation routes, modern fiction, the major-minor languages diatribe, the relationship among literatures, migration and diaspora, a reformulation of the literary canon, African Studies, Indian Studies, Afrindian Studies, the translation act of exoticising versus domesticating, and, finally, life writing and autobiography. Above all, it offers a unique opportunity to promote the literary fortunes of two writers who have much to tell the world, including the Hispanic part of it. Spain, its people and its publishing houses are very fond of translation. The fact that two Afrindian literature writers such as Dangor and Vassanji have translations of their works published in Spain proves this claim. But being translated into Spanish or Catalan does not guarantee a sound reception in Spain. The majority of Spanish readers are generally disinclined to choose texts coming from outside their cultural area of comfort (Europe or the Americas). Literature coming from Africa is always regarded as minority, alien, 
exotic, or difficult. No aggressive commercial policy has ever been promoted to make people aware of African literature. They were translated because of the interest of some academic circles or interest groups.

Another factor to take into account is the fact that the five texts have all been translated by a different translator. Translators therefore do not seem willing to accept another similar challenge or they do not have sufficient material to make a career out of this type of translation. Consequently, specialization in this kind of literature, or in one of these specific writers does not unfortunately happen.

Under these circunstances it may be difficult for both of them, Dangor and Vassanji, to be translated in Spain on a more well-established basis and get a strong readership, but it is not impossible, as the previous examples have shown. And above all, difficulty does not mean lack of interest, but rather the opposite. The building of a real world literature based on the circulation of works by means of translation only adds more points of interest to the Spanish and Catalan translations of the novels by Dangor and Vassanji, and their rarity can only be viewed as another one of their many attractions.

But things may change. More translation projects and the education of the younger generations towards the appreciation of those writers or literatures about which they may not know much must be a national priority. An undergraduate general course or a specialized master's degree within the framework of a Faculty of Translation Studies may also constitute the perfect catalyst that can make a difference in the future. Afrindian literature has much to offer. The number of works and words that qualify to be included in this corpus on Indian Ocean literature in the languages of Spain may be small at the moment, but it may become larger in the near future. ${ }^{9}$

Future or prospective translators of this type or another type of exotic texts, from the point of view of Spanish readerships, may consider exoticising as the best option. This study is an attempt to foreground, on the one hand, the significance of Dangor and Vassanji's texts in world literature and, on the other, exoticising as the most satisfying approach towards their translation. The complete texts by Dangor and Vassanji in Spanish translation should be taken into account alongside the other Afrindian writers that have also been translated into Spanish or any of the other official languages of Spain so that a compilation of sound data in this field would further their reception and foment future translations.

Reviews sent to author: $11 / 12 / 2020$

Revised paper accepted for publication: 31/01/2021

${ }^{9}$ Disbabelia, a University of Valladolid Press series devoted to texts and writers that have never been translated, or very rarely so, into Spanish or other languages of Spain, will publish an anthology of Indian Ocean writers in 2021. It will include translations into all the official languages of Spain: Catalan, Basque, Galician and Spanish. Consequently, this volume will struggle to popularize this literature and put an end to its status of minority reading. 


\section{WORKS CITED}

Anderson, Linda. Autobiography. Routledge, 2011.

Arkin, Anthony J., Karl P. Magyr \& Gerald J. Pillay (Eds.). The Indian South Africans. A Contemporary Profile. Owen Burgess, 1989.

British Council (s. a.). Achmar Dangor. The British Council. Literature. https://literature.britishcouncil.org/writer/achmat-dangor (accessed 6 February 2020).

Cornwell, Gareth, Dirk Klopper \& Craig Mackenzie. The Columbia Guide to South African Literature in English since 1945. Columbia University Press, 2010. https://doi.org/10.7312/ corn13046.

Damrosch, David. What is World Literature? Princeton University Press, 2003. https://doi. org/10.1515/9780691188645.

Dangor, Achmat. The Z Town Trilogy. Ravan Press, 1990.

Dangor, Achmat. Kafka's Curse. Kwela Books, 1997.

Dangor, Achmat. La maldición de Kafka. Translated into Spanish by Encarna Quijada Vargas. Seix Barral, 1999.

DANGor, Achmat. Bitter Fruit. Kwela Books, 2001.

Dangor, Achmat. Fruta amarga. Translated into Spanish by María Montserrat Vía Jiménez. El Cobre Ediciones, 2004.

Dangor, Achmat. Trilogía de Z Town. Translated into Spanish by Juanjo Estrella. Barcelona: El Cobre Ediciones / Casa África, 2009.

DAYMOnd, Margaret. "Imraan Coovadia's representation of the ambiguities of indian identity in pre- and post-apartheid Durban: The Wedding (2001) and High Low In-Between (2009)." in Felicity Hand \& Esther Pujolràs-Noguer (Eds.). Relations and Networks in South African Indian Writing. Cross Cultures, vol. 203. Brill, 2018. 138-152. https://doi. org/10.1163/9789004365032_010.

Essop, Ahmed. 2010. “Dos hermanas.” Trans. Sabrina Solar Solorzano. Hermēneus 12, 237-245.

Fernández Ruiz, María. Recepción del tercer espacio en el cuarto espacio: un estudio cuantitativo de la publicación y traducción de la literatura africana en España. Málaga: Universidad de Málaga. Unpublished PhD thesis, 2019.

Frenkel, Ronit. Reconsiderations. South African Indian Fiction and the Making of Race in Postcolonial Culture. Unisa Press, 2010.

Gopal, Priyamvada. The Indian English Novel. Nation, History, and Narration. Oxford University Press, 2009.

Govinden, Devarakshanam. A Time of Memory: Reflections on Recent South African Writing. Solo Collective, 2008.

Huddart, David. Postcolonial Theory and Autobiography. Routledge, 2014.

Karpinski, Eva C. Borrowed Tongues. Life Writing, Migration and Translation. Wilfred Laurier University Press, 2012.

LaL, Brij V. (Ed.). The Encyclopedia of the Indian Diaspora. University of Hawai'i Press, 2006.

Loomba, Ania. Colonialism / Postcolonialism. Routledge, 2005. 
Mishra, Vijay. "A Minor Literature." in Brij Lal (Ed.) The Encyclopedia of the Indian Diaspora. University of Hawai'i Press, 2006. 139.

Nord, Christiane. Translating as a Purposeful Activity. Functionalist Approaches Explained. St. Jerome, 1997.

Rastogi, Pallavi. Afrindian Fictions. Diaspora, Race, and National Desire in South Africa. Ohio State University Press, 2008.

Ratnakara Research Group. Indian Ocean Literatures and Cultures. Autonomous University of Barcelona, Spain. http://grupsderecerca.uab.cat/ratnakara/ (accessed 10 February 2020).

Roy, Modhumita. "What Memory Resists: Indenture, Apartheid, and the "Memory work" of Reconstruction in Ronnie Govender's Black Chin, White Chin." in Felicity Hand \& Esther PujolràsNoguer (Eds.). Relations and Networks in South African Indian Writing. Cross Cultures, vol. 203. Brill, 2018. 122-137. https://doi.org/10.1163/9789004365032_009.

Toury, Gideon. Descriptive Translation Dtudies - and Beyond. John Benjamins, 2012. https://doi. org/10.1075/btl.4.

Түмосzкот, Maria. "Post-colonial Writing and Literary Translation." Susan Bassnett and Harish Trivedi (Eds.). Post-colonial Translation. Theory and Practice. Routledge, 1999. 19-57. https:// doi.org/10.4324/9780203068878.

Vassanj, Moyez G. The In-Between World of Vikram Lall. Canongate Books, 2004.

Vassanj, Moyez G. El mundo incierto de Vikram Lall. Translated into Spanish by Gemma Rovira Ortega. Ediciones Salamandra, 2006a.

Vassanjı, Moyez G. La pàtria aliena de V. Lall. Translated into Catalan by Xavier Pàmies Jiménez. RBA Libros, 2006b.

Vassanji, Moyez G. The Assassin's Song. Doubleday, 2007.

Vassanji, Moyez G. A Place Within. Rediscovering India. Anchor Canada, 2009.

Vassanji, Moyez G. And Home was Kariakoo: A Memoir of East Africa. Doubleday Canada, 2014.

Xu, Susan. Translation of Autobiography. Narrating Self, Translating the Other. John Benjamins, 2017. https://doi.org/10.1075/btl.136.

Zarandona, Juan. "El corpus de traducciones españolas de Chinua Achebe (1930-): traducción sincrónica y diacrónica comparada de los traductores." Afroeuropa. Journal of Afroeuropean Studies 4/1 (2010): 1-22. http://journal.afroeuropa.eu/index.php/ afroeuropa/article/ view/167/158 (accessed 14 February 2020).

Zarandona, Juan. "Argon Valley o la utopía sudafricana de Ahmed Essop (1931-), o reflexiones por qué el cuento "The Pagans» nunca se traducirá al español." Futhark. Revista de Investigación 10, (2015):131-141.

Zarandona, Juan. "South African Indian Ahmed Essop in Spanish translation: 'Dos hermanas' (2010), a story of many linguistic and cultural barriers." in Sharmilla Beezmohun (Ed.). Continental Shifts, Shifts in Perception. Black Cultures and Identities in Europe. Cambridge Scholars Publishing, 2016. 151-169.

Zarandona, Juan. "The reception of Ahmed Essop in Spain: Or, the race factor in the comparative literary reception of contemporary South African writers in Spain." in Felicity Hand \& Esther Pujolràs-Noguer (Eds.). Relations and Networks in South African Indian Writing. Cross Cultures, vol. 203. Brill, 2018a. 56-74. https://doi.org/10.1163/9789004365032_005. 
Zarandona, Juan. "The Third Prophesy (2004) de Ahmed Essop (1931-) o los retos de traducción de la vida y carrera profesional de Salman Khan, ministro de Educación de origen Indio en la Nueva Sudáfrica.” in Miguel Ángel García Peinado \& Ignacio Ahumada Lara (Eds.). Traducción literaria y discursos traductológicos especializados. Peter Lang, 2018b. 107-125.

Zarandona, Juan. Afrindian Writers in Spanish Translation Corpus Project, 2020. https:// www.researchgate.net/project/Afrindian-writers-in-Spanish-translation. https://doi. or/10.1163/9789004365032_005. 
